\title{
Chemical and electric transmission in the carotid body chemoreceptor complex
}

\author{
CARLOS EYZAGUIRRE
}

Department of Physiology, University of Utah School of Medicine, Research Park, Salt Lake City, Utah, USA

\begin{abstract}
Carotid body chemoreceptors are complex secondary receptors. There are chemical and electric connections between glomus cells (GC/GC) and between glomus cells and carotid nerve endings (GC/NE). Chemical secretion of glomus cells is accompanied by GC/GC uncoupling. Chemical GC/NE transmission is facilitated by concomitant electric coupling. Chronic hypoxia reduces GC/GC coupling but increases G/NE coupling. Therefore, carotid body chemoreceptors use chemical and electric transmission mechanisms to trigger and change the sensory discharge in the carotid nerve.
\end{abstract}

Key terms: carotid body, chemosensory activity, glomus cells.

The subject of this short review is highly appropriate since we are honoring Prof. Patricio Zapata who has been a pioneer in this field and has done extensive pharmacological studies on chemical synaptic transmission in the carotid body. Dr. Zapata is an excellent scientist and teacher, and I dearly value him as a friend and colleague.

\section{NATURE OF THE CAROTID BODY INNERVATION}

The principal histological structures in the carotid body are the glomus cells that are innervated by fibers of the carotid nerve. De Castro (1926) proposed that the innervation of the glomus cells was sensory, since section of the carotid nerve led to degeneration of the carotid nerve fibers, whereas section of the motor roots did not. The sensory nature of the carotid nerve fibers was reinforced by physiological experiments, since section of this nerve prevented respiratory reflexes originating from the carotid body-sinus area (Heymans and Neil, 1958; Anichkov and Belen'kii, 1963).
Years later, with the advent of the electron microscope, it was found that the glomus cells were connected synaptically to the carotid nerve endings (for refs. see Mc Donald, 1981; Verna, 1997). Then, the problems started because of the location of clear core synaptic vesicles. At the time, these structures were supposed to be a marker of pre-synaptic elements, and in the carotid body, they appeared some times in the glomus cells but very often in carotid nerve endings. Furthermore, Neil and O'Regan (1971), in physiological experiments, found an efferent pathway traveling in the carotid nerve. Consequently, the sensory innervation of the carotid body came into question, and this culminated with the ablation experiments of Biscoe et al. (1970), in which they indicated that the synaptic innervation of glomus cells was efferent. The afferent innervation of the organ was relegated to loose nerve fibers in the stroma.

At this point, the intervention of Prof. Zapata was crucial. Hess and Zapata (1972), in a seminal study, carefully 
repeated de Castro's nerve surgery and used morphological (light and electron microscopy) and physiological techniques to study normal and operated animal specimens. Their results definitely confirmed de Castro's results and established without doubt that the major innervation of the carotid body is sensory. Many other investigators working on different mammalian species confirmed their results. The efferent innervation originally described by Neil and O'Regan appeared to be confined to unmyelinated fibers in the carotid nerve (Fidone and Sato, 1970) going to innervate blood vessels in the carotid body (Belmonte and Eyzaguirre, 1974)

CHEMICAL TRANSMISSION BETWEEN GLOMUS CELLS AND CAROTID NERVE ENDINGS

There have been several hypotheses (metabolic, acidic, transmitter, etc.) in the attempt to explain the onset of discharges in the carotid nerve (Heymans and Neil, 1958; Anichkov and Belen'kii. 1963). Nowadays, we accept parts of the acidic and metabolic hypotheses, since there are useful elements in each one. However, the most accepted idea today is that there is chemical transmission across the glomus cell-nerve ending junctions. This is an operational idea that does not tell us what mechanisms are involved in transmitter production and release. We know little about these mechanisms.

The first indications that the sensory junction in the carotid body was chemical derived from two observations. One was the detection, under the electron microscope, of dark core granules in the glomus cells; the other was the finding that glomus cells contained catecholamines, especially dopamine, detected with the Falk-Hillarp technique for the light microscope. Acetylcholine $(\mathrm{ACh})$ was also found in carotid body tissue in normal and chronically denervated organs (Eyzaguirre et al., 1965, Fidone et al., 1976; Gual and Marsal, 1987). These early findings have been amply confirmed and expanded by Fitzgerald's group (2000).
Chemical release from a stimulated carotid body was first demonstrated by Eyzaguirre et al. (1965) using a Loewi-type preparation, which consisted of two carotid bodies in series in a narrow channel through which flowed physiological solution bathing both organs. Stimulation of the upstream organ induced changes in the carotid nerve discharges of the downstream preparation. Dr. Zapata performed pharmacological tests showing that the downstream organ was responding to $\mathrm{ACh}$ released from the upstream preparation (Eyzaguirre and Zapata, 1968). More recently, Fitzgerald and his group also have shown ACh release from the carotid body during hypoxic and hypercapnic stimulation (Fitzgerald, 2000).

The studies previously mentioned have been conducted in cat carotid bodies, and in this species, it seems likely that excitatory transmission is cholinergic with dopamine playing an inhibitory role (Zapata, 1997b; Varas et al., 2003; Iturriaga and Alcayaga, 2004). A different story occurs in rabbit carotid body chemoreceptors, where the bulk of physiological and biochemical evidence points out that DA is the excitatory transmitter, whereas $\mathrm{ACh}$ is inhibitory (Monti-Bloch and Eyzaguirre, 1980; Gonzalez et al., 1994; Zapata, 1997b). There is relatively little information about rat carotid body receptors, but it seems that in this species, excitatory transmission also is cholinergic (Zhang et al., 2000). However, the jury is still out.

$\mathrm{ACh}$ and dopamine are not the only actors in chemosensory synaptic transmission. Glomus cells contain, in addition, several compounds whose concentration changes during hypoxia, and some of them are released from the cells. These are: serotonin (5-HT), enkephalins, prostaglandins, ATP, substance $\mathrm{P}$, and peptides (cholecystokinins, atrial natriuretic peptide-ANP). Hypoxia produces several changes. 1) It increases intracellular cAMP, while decreasing cGMP. 2) It releases ATP from the dark core granules, which turns into adenosine by ectonucleotidases. This process may activate the cell membranes because of the presence of $\mathrm{P} 1$ purinergic 
receptors for ATP and P2 for adenosine. 3) It increases the synthesis of endogenous prostaglandin E2 (PGE2), which inhibits inward calcium currents when exogenously applied (for refs. see Zapata, 1997b).

These findings lead us to consider that the pre-synaptic element of the chemosensory synapse is the glomus cell. The chemical contents of these cells seem to be almost the same in all species. However, the post-synaptic membranes of the nerve endings seem to differ depending on the animal species. Another consideration is that the synapses may not be solely unidirectional, since afferent impulses in the carotid nerve may cross the junction and affect transmitter release. It should be remembered that McDonald (1981) has described synapses oriented from nerve to cell. Nevertheless, as shown below, available physiological evidence does not support this possibility.

\section{ELECTRIC TRANSMISSION BETWEEN GLOMUS}

CELLS AND BETWEEN GLOMUS CELLS AND NERVE ENDINGS

There are gap junctions between glomus cells (McDonald, 1981; Abudara et al., 1999) and similar connections have been described between glomus cells and carotid nerve endings (Kondo and Iwasa, 1996). However, later on, Kondo (2002) expressed doubts about his earlier findings.

We have found clear evidence for electric connections between glomus cells, GC/GC coupling (Monti-Bloch et al., 1993; Eyzaguirre and Abudara, 1995, 1999), with coupling channels behaving similarly to those in other tissues (Abudara et al., 2001, 2002). Furthermore, injections of dye (Procion Blue, Lucifer Yellow) into one glomus cell spreads to other coupled cells (Baron and Eyzaguirre, 1977; Eyzaguirre et al., 2003). Different stimuli (hypoxia, hypercapnia, acidity, and chemical transmitters) uncouple most glomus cells. Chronic hypoxia also reduces coupling between them.

In spite of morphological uncertainties about connections between glomus cells and carotid nerve endings, we have found electric coupling between these elements (GC/NE coupling). Also, injections of Lucifer Yellow into a glomus cell spreads to the nerve ending (Eyzaguirre et al., 2003; Jiang and Eyzaguirre, 2003a, b). GC/NE coupling is mostly unidirectional, from glomus cell to nerve ending, since coupling in the opposite direction - from nerve to cell (NE/GC) - is minimal.

There are no pharmacological experiments testing the effects of acute hypoxia, hypercapnia, acidity or transmitters on glomus cell-nerve ending coupling. However, chronic hypoxia increases this type of coupling.

\section{CONCLUSIONS}

The carotid body is a very complex sensory receptor that, most likely, generates the sensory discharge by chemical and electric transmission across the chemosensory junction.

We have suggested that stimulated and secreting glomus cells uncouple during this process (Eyzaguirre and Abudara, 1999), as occurs in exocrine glands. We are now proposing that chemical transmission across the glomus cell-nerve ending junction is aided by electric coupling between these structures. This assumption is based on the fact that chronic hypoxia increases $\mathrm{GC} / \mathrm{NE}$ coupling and that, under this condition, the receptors are more responsive to natural (hypoxia, hypercapnia) stimuli and exogenous application of transmitters (Rey et al., 2004; He et al., 2005). Increased GC/ $\mathrm{NE}$ coupling also may be a factor in depressing or preventing the effects of specific synaptic blockers on natural carotid body stimulation. However, the release of multiple transmitters during carotid body stimulation also should play an important role in preventing the actions of a specific blocker (Zapata, 1997a, b).

A puzzling observation has been that we have not found a post-synaptic potential during stimulation of glomus cells or nerve endings while recording from apposed nerve endings or glomus cells. This finding is puzzling because chemical synapses between glomus cells and nerve endings and between 
glomus cells are amply documented (McDonald, 1981; Verna, 1997). We do not have a ready explanation for this non-effect. However, dual stimulation and recording from glomus cells and nerve endings have been done only in rat carotid bodies. In this species, glomus cells have very few $\mathrm{Na}+$ and calcium voltage-gated channels (Fieber and McCleskey, 1993; Jiang et al., 1998; Jiang and Eyzaguirre, 2005). They may be unexcitable electrically, according to Grundfest's (1961) definition. A different story may appear if dual stimulation and recordings are performed in rabbit chemoreceptors where glomus cells clearly have voltage-gated sodium and calcium channels (for references see Gonzalez et al., 1994).

\section{ACKNOWLEDGEMENTS}

This work was supported by NIH grant NS 07938 .

\section{REFERENCES}

ABUDARA V, GARCES G, SÁEZ JC (1999) Cells of the carotid body express connexin43, which is upregulated by cAMP. Brain Res 849: 25-33

ABUDARA V, JIANG RG, EYZAGUIRRE C (2001) Acidic regulation of junction channels between glomus cells in the rat carotid body: Possible role of [Ca2+]i. Brain Res 916: 50-60

ABUDARA V, JIANG RG, EYZAGUIRRE C (2002) Behavior of junction channels between rat glomus cells during normoxia and hypoxia. J Neurophysiol 88: 639649

ANICHKOV SV, BELEN'KII ML (1963) Pharmacology of the Carotid Body Chemoreceptors. New York: Pergamon. pp: 225

BARON M, EYZAGUIRRE C (1977) Effects of temperature on some membrane characteristics of carotid body cells Am J Physiol Cell Physiol 2: C35-C46

BELMONTE C, EYZAGUIRRE C (1974) Efferent influences on carotid body chemoreceptors. J Neurophysiol 37: 1131-1143

BISCOE TJ, LALL A, SAMPSON SR (1970) Electron microscopic and electrophysiological studies on the carotid body following intracranial section of the glossopharyngeal nerve. J Physiol (Lond) 208: 133-152

DE CASTRO F (1926) Sur la structure et l'innervation de la glande intercarotidienne (glomus caroticum) de 1 'homme et des mammiferes et sur un nouveau systeme d'innervation autonome du nerf inter carotidien. Trab Lab Invest Biol 24: 365-432

EYZAGUIRRE C, KOYANO H, TAYLOR JR (1965) Presence of acetylcholine and transmitter release from carotid body chemoreceptors. J Physiol (Lond) 178: 463-476
EYZAGUIRRE C, ZAPATA P (1968) The release of acetylcholine $(\mathrm{ACh})$ from carotid body tissues. Further study on the effects of ACh and of cholinergic blocking agents on the chemosensory discharge. J Physiol (Lond) 195: 589-607

EYZAGUIRRE C, ABUDARA V (1995) Possible role of coupling between glomus cells in carotid body chemoreception. Biol Signals 4: 263-270

EYZAGUIRRE C, ABUDARA V (1999) Carotid body glomus cells: Chemical secretion and transmission (modulation?) across cell-nerve ending junctions. Resp Physiol 115: 135-149

EYZAGUIRRE C, JIANG RG, ABUDARA V (2003) Electric and dye coupling between rat carotid body cells and between these cells and carotid nerve endings. In: LAHIRI S, SEMENZA G, PRABHAKAR $\mathrm{N}$ (eds) Oxygen Sensing: Responses and Adaptation to Hypoxia. New York: Marcel Dekker. pp: 331-352

FIDONE SJ, SATO A (1970) Efferent inhibition and antidromic depression of chemoreceptor A-fibers from the cat carotid body. Brain Res 22: 181-193

FIDONE SJ, WEINTRAUB ST, STAVINOHA WB (1976) Acetylcholine content of normal and denervated cat carotid bodies measured by pyrolysis gas chromatography/mass fragmentometry. J Neurochem 26: 1047-1049

FIEBER LA, McCLESKEY EW (1993) L-type calcium channels in Type I cells of the rat carotid body. J Neurophysiol 70: 1378-1384

FITZGERALD RS (2000) Oxygen and carotid body chemotransduction: The cholinergic hypothesis - A brief history and new evaluation. Respir Physiol 120: 89-104

GONZALEZ C, ALMARAZ L, OBESO A, RIGUAL R (1994) Carotid body chemoreceptors: From natural stimuli to sensory discharges. Physiol Rev 74: 829-98

GRUNDFEST H (1964) Evolution of electrophysiological varieties among sensory receptor systems. In: Essays on Physiological Evolutions. New York: Pergamon. pp: 107-138

GUAL A, MARSAL J (1987) Application of the chemiluminescence method to carotid body for detecting choline and acetylcholine. In: RIBEIRO JA, PALLOTT DJ (eds). Chemoreceptors in Respiratory Control. London: Croom Helms. pp: 108-113

HE L, DINGER B, FIDONE S (2005) Effect of chronic hypoxia on cholinergic chemotransmission in rat carotid body. J Appl Physiol 98: 614-619

HESS A, ZAPATA P (1972) Innervation of the cat carotid body: Normal and experimental studies. Fed Proc 31: 1365-1384

HEYMANS C, NEIL E (1958) Reflexogenic Areas of the Cardiovascular System. London: Churchill. pp: 207

ITURRIAGA R, ALCAYAGA J (2004) Neurotransmission in the carotid body: Transmitters and modulators between glomus cells and petrosal ganglion nerve terminals. Brain Res Rev 47: 46-53

JIANG RG, ZHANG XQ, EYZAGUIRRE C (1998) Hypoxia induced by $\mathrm{Na} 2 \mathrm{~S} 2 \mathrm{O} 4$ increases $[\mathrm{Na}+] \mathrm{i}$ in mouse glomus cells, an effect depressed by cobalt. Experiments with $\mathrm{Na}+$-selective microelectrodes and voltage clamping. Brain Res 797: 197-208

JIANG RG, EYZAGUIRRE C (2003a) Dye and electric coupling between carotid nerve terminals and glomus cells. Adv Exp Med Biol 536: 247-253

JIANG RG, EYZAGUIRRE C (2003b) Effects of hypobaric hypoxia on the intercellular coupling of glomus cells Adv Exp Med Biol 536: 565-567

JIANG RG, EYZAGUIRRE C (2005) Calcium channels of cultured rat glomus cells in normoxia and acute hypoxia. Brain Res 1031: 56-66 
KONDO H, IWASA H (1996) Re-examination of the carotid body ultrastructure with special attention to intercellular membrane appositions. Adv Exper Med Biol 410: 45-50

KONDO H (2002) Are there gap junctions between chief glomus, (type I) cells in the carotid body chemoreceptor? Microsc Res Tec 59: 227-233

MONTI-BLOCH L, EYZAGUIRRE C (1980) A comparative physiological and pharmacological study of cat and rabbit carotid bodies. Brain Res 193: 449470

MONTI-BLOCH L, ABUDARA V, EYZAGUIRRE C (1993) Electrical communication between glomus cells of the rat carotid body. Brain Res 622: 119-131

MCDONALD DM (1981) Peripheral chemoreceptors: Structure-function relationships of the carotid body. In: HORNBEIN TF (ed) Regulation of Breathing. New York: Marcel Dekker. pp: 105-320

NEIL E, OREGAN RG (1971) The effects of electrical stimulation of the distal end of the cut sinus and aortic nerves on peripheral arterial chemoreceptor activity in the cat. J Physiol (Lond) 215: 15-32

REY S, DEL RÍO R, ALCAYAGA J, ITURRIAGA R
(2004) Chronic intermittent hypoxia enhances cat chemosensory and ventilatory responses to hypoxia. J Physiol (Lond) 56: 577-586

VARAS R, ALCAYAGA J, ITURRIAGA R (2003) ACh and ATP mediate excitatory transmission in cat carotid identified chemoreceptor units in vitro. Brain Res 988: 154-163

VERNA A (1997) The mammalian carotid body: Morphological data. In GONZÁLEZ C (ed). The Carotid Body Chemoreceptors. New York: Springer. pp: $1-29$

ZAPATA P (1997a) Chemosensory activity in the carotid nerve: Effects of physiological variables. In GONZÁlEZ C (ed) The Carotid Body Chemoreceptors. New York: Springer. pp: 97-118

ZAPATA P (1997b) Chemosensory activity in the carotid nerve: effects of pharmacological agents. In GONZÁlEZ C (ed) The Carotid Body Chemoreceptors. New York: Springer. pp: 119-146

ZHANG M, ZHONG H, VOLLMER C, NURSE CA (2000) Co-release of ATP and ACh mediate hypoxic signaling at rat carotid body chemoreceptors. J Physiol (Lond) 525: $143-158$ 